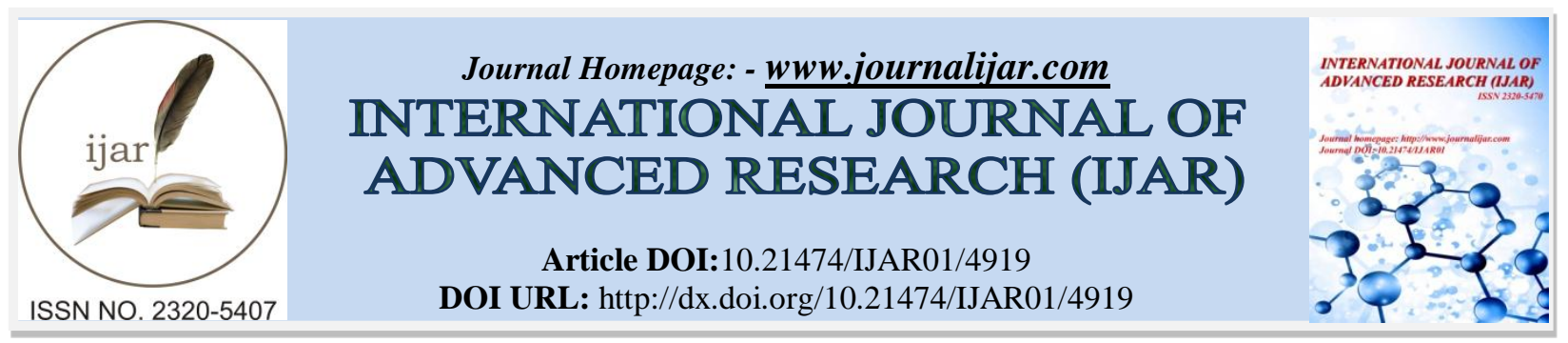

RESEARCH ARTICLE

\title{
COVERAGE OF MINORITY ISSUES IN THE PAKISTANI ELECTRONIC MEDIA.
}

Sidra Shehzadi.

Institute of Communication Studies, Punjab University, Pakistan.

\section{Manuscript Info}

Manuscript History

Received: 22 May 2017

Final Accepted: 24 June 2017

Published: July 2017

Key words:-

ideology, ethnocentrism, minority issues,

sensationalized, national integrity,

electronic media.

\section{Abstract}

In present study that focused the coverage of minority issues by Pakistani electronic media, objectively the issue of Kot Radha Kishan Lahore and said the survey questionnaire from the audience. Study having research questions of whether media sensationalized that incident, and leading news channels reporting supportive to national integrity. Research also measured the response of public regarding that issue. Most people agreed that media objectively covered that incident, and channels gave importance to minority issues with an ethnic tilt. Fifty percent people approved that media channels fueled conflict between Muslims and non-Muslims by reporting minority issues.

Copy Right, IJAR, 2017,. All rights reserved.

\section{Introduction:-}

Media is considered the fourth pillar of the state and one of the most important preconditions for development in any country (Raza \& Khan, 2014). It represents the beliefs and culture of any nation from which it belongs to. But when there is a nation of multiple beliefs and opinions (Abu Bakar \& McCann, 2016), so it becomes the challenge for media to whom opinion highlight or not. In the perspective of Pakistan, a variety of cultures and beliefs exists, and if it relates to the term ethnocentrism; which means a preference of one's own culture and ideology as compare to others (Raza \& Awan, 2013). In this condition media should neutral to stress on all types of issues regarding any culture (Sung, 2014).

Ethnic refers to the "cultural heritage" and centrism refers to the "central starting point". (Hsu \& Barker, 2013) Ethnocentrism is the tendency to believe that one's ethnic or cultural group is centrally important and that all other groups are measured in relation to one's own. William G. Summer presented the term "ethnocentrism" in 1907 by noticing people's attitude toward their own and others group of people. He described it as the thing in which one focus and concentrates own values and believes. The ethnocentric individual judge others culture according to his/her own ethnic group or culture, especially language, customs and religion. He added that it often causes to pride, superiority about one's own group (Zhang, 2006).

The place where people spend their whole life, accepted the culture, values and behavior of it and think, act according to their beliefs, society to which they consider their norms (Bakar, Mohamad, \& Mustafa, 2007). If people experience other traditions with different cultural norms they will realize that this culture does not resemble with their birth culture. It is difficult for them to accept and adopt other traditions (Ho, Chen, \& Sim, 2013). In Pakistan variety of culture exists like Sindhi, Balochi, Punjabi, and Pathan with multiple norms, values, languages. Along with different issues in Pakistan political, economic, and social as well (Raza \& Hussain, 2016). Ethnocentrism there among people, everyone feels superior their culture and traditions. 
Ethnocentrism to some extent plays an essential role in raising solidarity and harmony among group members. It is the root cause of patriotic spirit (Okazaki, Mueller, \& Taylor, 2010). Ethnocentrism eliminates major or minor conflicts from society, but ethnocentrism generalizes others on limited experience. It only identifies in-group culture and norms and thinks others inferior to him. It creates stereotype thinking and hatred, violence and conflict among people. Ethnocentrism blocks the growth of knowledge and development of the nation (Shan \& King, 2015).

In the context of Pakistani media Urdu press in Pakistan, has been most careless and irresponsible in the world as it has always been a treat in promoting such conspiracy concepts that can be harmful to the union of all provinces and its national image inside and outside the country (Raza \&Waheed, 2016). Pakistani Urdu press media is fading the national values by relying on the propaganda and prejudice views.

Also, by now today, the existing media groups are controlled by the corporate and business interests, and some owners use such groups as guarding cover for the interests of their business, hence, these owners are not media individuals. For example, Urdu, Daily Express owned by Mr. Lakhani, who also is the head of American based fast food chain McDonalds within Pakistan.

Pakistani media cannot be ethnocentric in nature because it leads to racial conflicts. But all are Pakistani and mostly Muslims. Media should reflect whole nation. It must respect and maintain the relationship between in-group and out group. Its products regarding news, talk shows, advertising, dramas etc. cannot ethnocentric at all.

\section{Statement of the problem:-}

The researcher is focused to find out the "performance of Pakistani media regarding minority issues". The reason for selecting this topic is that media only dominate minority issues when it happened, before and after media did not talk about minority issues and policy by the government about them. That's why researcher intends to find out the role of electronic media in coverage of minority issues.

\section{Rationale of the study:-}

Researcher provoked to find out the performance of electronic media regarding minority issues in Pakistan. Rather news coverage and reporting support minority, or only sensitizing these issues for their ratings.

\section{Rationale for selecting electronic media:-}

Electronic media got importance among people due to its high effect and access to all audience. As mentioned by $\mathrm{TV}$ has become the strongest form of media to perform functions of information, education, influence and entertainment.

\section{Rationale for selecting leading news channels:-}

Leading news channels of electronic media selected for the present study, because public prefer to watch television as compared to read a newspaper and consult TV for exclusive and breaking news and reports. People only switch the channel of their desire.

\section{Rationale for selecting Kot Radha Kishan issue for research:-}

The researcher selected Kot Radha Kishan issue for present discussion, because it nearly relates to the ethnocentric attitude of the public and can evaluate media rather it justifies the minority issue or has an ethnocentric view on it, and to know about audience opinion about coverage of the incident.

\section{Literature Review:-}

Media have been used extensively to strengthen national identity and to increase faithfulness among citizens through production and diffusion of one national culture, promoting national harmony, unity, devotion, and integration especially through mass media in the country (Raza, Bakar, \& Mohamad, 2017). Media can help create and reinforce a sense of national unity and belonging by encouraging people living in different parts of the country to visualize and feel kindness and oneness with other readers, viewers, or listeners, simultaneously consuming the same media products in the country (Wang \& Li, 2012). Louis Alvin day agrees that "regardless of the source of information, society has a right to expect a certain level of ethical behavior from its media institutions and when this conduct is not forthcoming, a crisis of confidence occurs between these institutions and the public (Scheufele \& Tewksbury, 2007). David Gordon argues that freedom of expression must be protected at almost any cost, regardless of whether the media are ethical or responsible. 
Analyzing Pakistani media; its society believes that its fourth pillar of the state that is media should follow ethical values that defined its religion and culture (Raza, Kaharal, \& Bhatti, 2017; Raza \& Liaqat, 2016). For example, now a day's running news regarding drawings about last Prophet Peace Be upon Him by Charlie Hebdo Francis weekly magazine, strictly condemn by Muslims all around the world, all that possible by media institutions, all Pakistani's and Muslims protest that and government of Pakistan, all officials, religious parties convey messages and speeches by Pakistani media channels and social networking sites. Because of the reason; that is ethnocentric thought of Pakistani people and Muslims regarding their religion and cultural beliefs. And also, the ethnocentric thinking of Francis regarding Muslims, media should resolve that conflict by different media products, and create harmony with the world nations.

If all mankind minus one were of one opinion, mankind would be no more justified in silencing that one person than he, if he had the power, would be justified in silencing mankind (Bohensky \& Leitch, 2014). Were an opinion a personal possession of no value except to the owner; if to be obstructed in the enjoyment of it were simply a private injury, it would make some difference whether the injury was imposed only on a few persons or on many. But the strange evil of silencing the expression of an opinion is, that is depriving the human race; posterity as well as the existing generation; those who disagree with the opinion, still more than those who hold it (Groshek \& Han, 2011).

Blasphemy is a sensitive subject in Pakistan, a nation of 180 million people, 97 per cent are Muslims and those convicted of defaming Islam can face life imprisonment or even the death penalty. At Joseph colony in Badami Bhag a Christian man falsely accuses of blasphemy and mob attacked Christian colony. At least 160 houses, 18 shops and 2 small churches were burnt by protesters. There was no loss of life but 20 policemen injured. Media aired and printed on the subject, the Muslims ethnocentric judgment and about Christian blasphemy and the loss of Christian minorities.

Mentioned by journalists should examine their own cultural values and avoid imposing those values on other, avoid stereotyping by race, gender, age, religion, ethnicity, geography, sexual orientation, disability, physical appearance or social status. Support the open exchange of views, even views they find disgusting (Newman, Dutton, \& Blank, 2012). At BBC news Asia, another report regarding minority in Pakistan; angry crowd have beaten Christian couple over 'blasphemy and later set their bodies on fire in Kot Radha Kishan in Punjab province. An incident like these media started back to back talk shows, exclusive stories and reporting on minorities. Talk shows were having the only leg pulling by guests of the show, who are politicians and government officials. Day by day media forget to talk about rights of minorities in Pakistan, which discuss their issues and report to the government. Through analyzing this weird behavior of media, we can say that it is ethnocentric in nature(Sparks, 2007).

Analyzing the results of the survey concluded that media is promoting three elements, which are violence, vulgarism and chaos amongst which chaos is important. Television damages social, moral and religious values and negatively influences human behavior (Greenberg \& Mastro, 2009). It violates ethical norms and disputes the integrity of cultures. As cited in interviewed from people for the book about advertising; Ben Gold Hirsch, the publisher of Good Magazine said advertising was about generating revenue. Also, Alan Khazei from city year said advertising provided his organization a chance to "put out our values and ideals.

In Pakistani ads, media don't glorify its nation culture like Punjabi, Sindhi etc. but only focuses on glorifying women, rather the ad needed it or not like service tire, sanitary fittings etc. Media supporting foreign culture in which they mainly concentrate on portraying female as a catchy factor to increase their consumerism and production for profits (Pandyan, 2013). Media must be neutral and not impartial or ethnocentric as well (Chan, Tsang, \& Ma, 2015). By using certain imagery portrayed in the media, being slim fashion models, a character in a television drama or a lyric from a popular song, young people and even adults can construct an identity for them. Individuals actively and creatively sample available cultural symbols, myths, and rituals as they produce their identities. For teens, the mass media are central to this process because they are a convenient source of cultural options.

Ethnocentrism opposes internationalism; ethnocentrism is related to nationalism, culture structure, lifestyles, corporate identity, national identity, and a shortage of domestic alternatives (Siegel, 2016). Pakistan is a diverse society where every group, race, casts and creed wants its domination on media organization. They want to introduce and cultivate their specific culture, values, norms and ideology. Every group attempts to influence media to get maximum and positive coverage that effects on media content (McCombs \& Shaw, 1972). These researches strengthen the present topic, which examines the performance of electronic media in the perspective of minority issues. Other researches explore the different aspects of the topic and highlight ethnocentrism in different 
perspectives. On the basis of literature review this research can be broken down into following research questions and objectives;

\section{Research questions:-}

1. Is media reporting concerning Kot Radha Kishan helps to strengthen nationalism?

2. Has leading news channels sensationalized Kot Radha Kishan incident?

3. Has public satisfied with the coverage on Kot Radha Kishan issue?

Objectives of the study:-

The study designed to achieve the following objectives:

1. To identify rather leading news channels impartially presented Kot Radha Kishan issue.

2. To measure the reaction of public towards media performance regarding news selection and reporting on Christian couple incident.

3. To find out media treatment related to Kot Radha Kishan promoting national solidarity or sensationalism in public.

\section{Hypotheses:-}

1. Kot Radha Kishan incident fairly presented by leading news channels.

2. Public opinion regarding Kot Radha Kishan issue associated with the presentation by news treatment.

\section{Research Method:-}

The researcher selected quantitative method for the present study. Pakistani electronic media impact on the public is measured through survey method. The questionnaire was developed to explore the opinions of the target audience about the role of media in Pakistan regarding ethnocentric version or neutrality related to media production. Questionnaire supported by information drawn from literature. People of university selected for the data collection. The university of Punjab is chosen as population, for the convenience of the researcher. Data were collected from 30 participants through convenient sampling including male and female, age from 25-35-years old. Pakistani media is the independent variable in the research from which electronic media is selected. Electronic media included leading news channels of Pakistan. Minority issue such as Christian couple burnt alive is a dependent variable that depends on the coverage of media. The treatment and presentation of Christian couple issue at Lahore by leading news channels.

\section{Data analysis and findings:-}

The researcher has conducted the survey; following data presentation is about that survey gathered from selected sample.
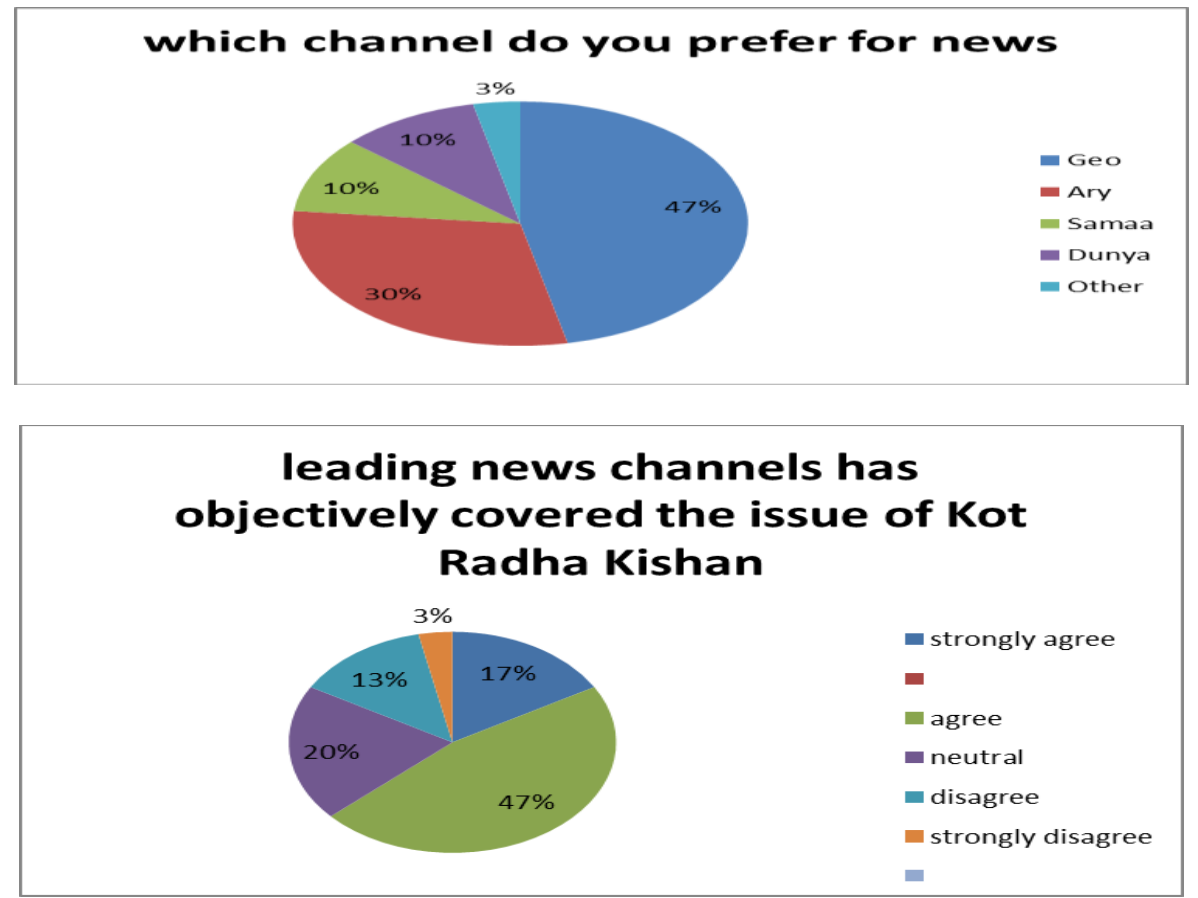

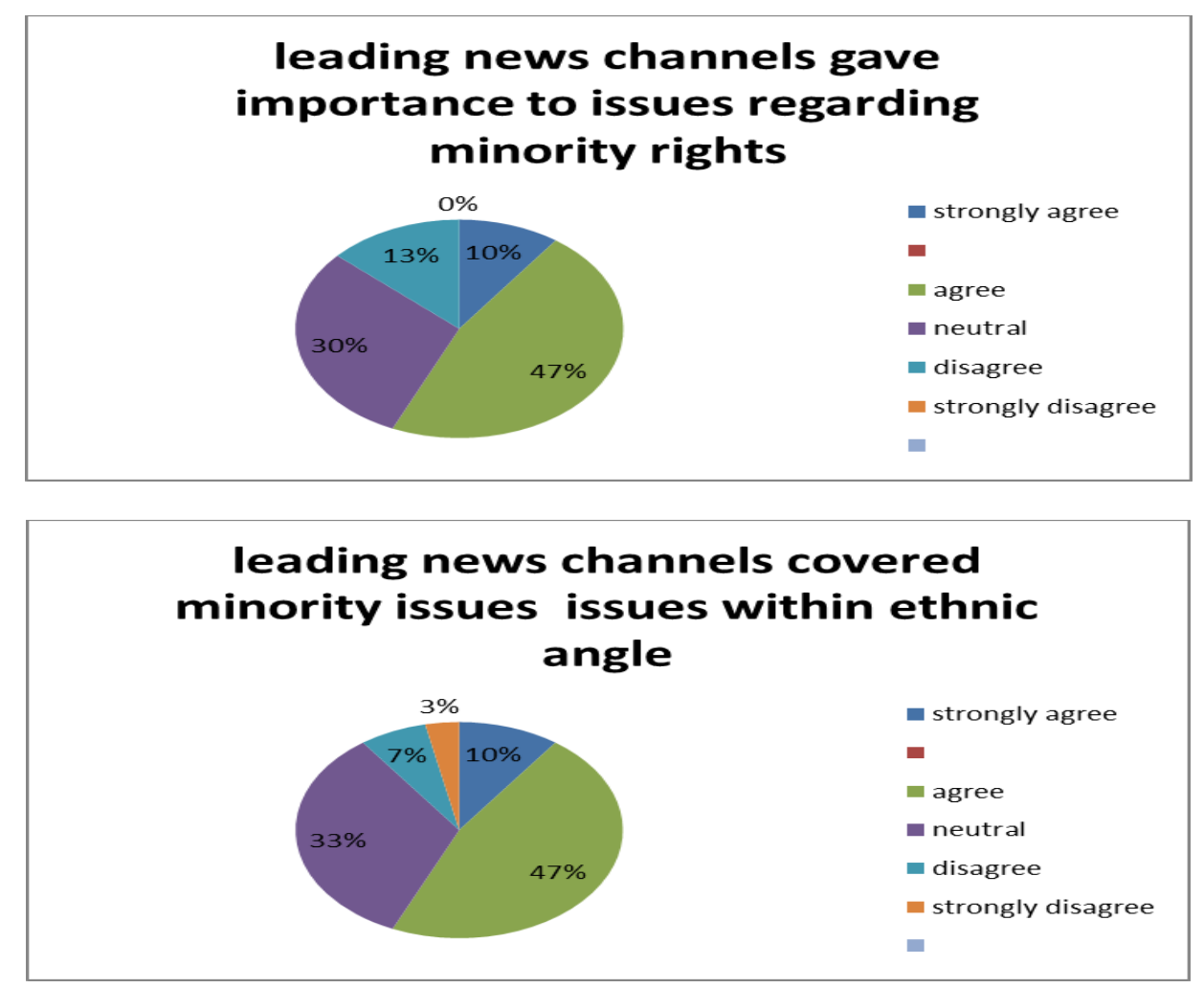

leading news channels coverage on kot radha kishan issue issue support patriotism
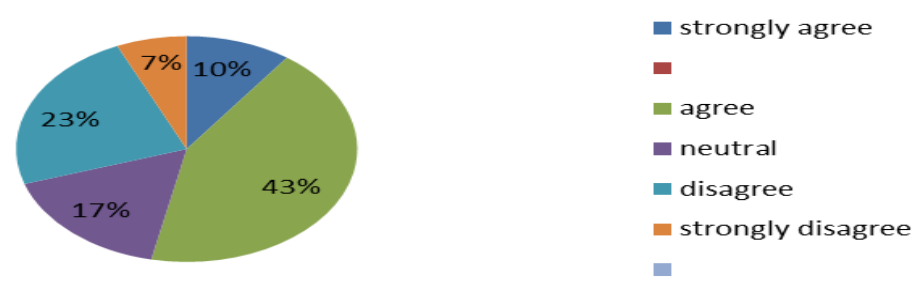

\section{leading news channels presented} both sides of picture while covering the incident
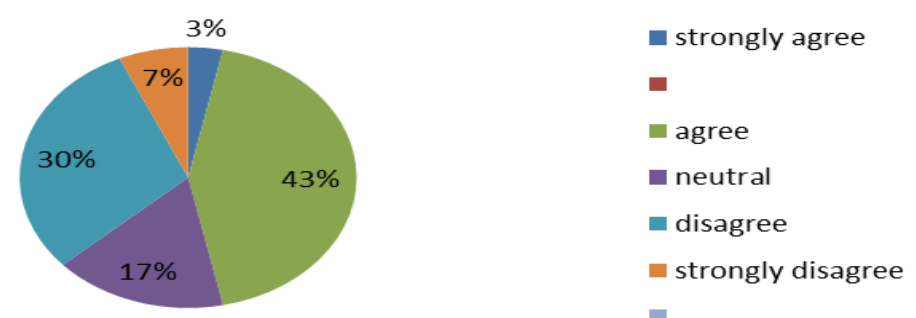

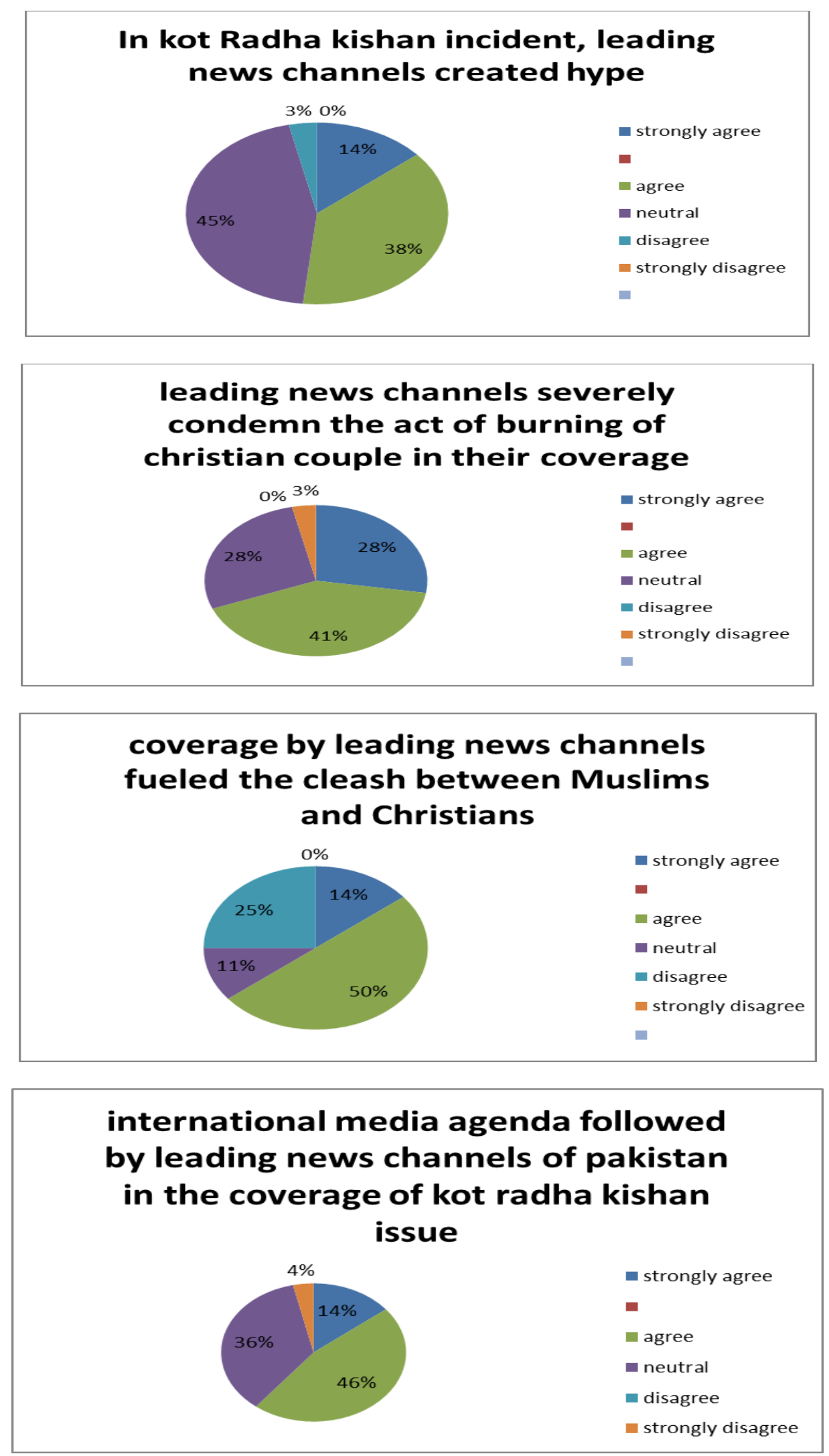

Each diagram presented above shows the percentage of every question that was asked from the target audience, in the survey that was conducted on minority issues covered by leading news channels. 


\section{Discussion and conclusion:-}

In the present study, the researcher was intended to find out the coverage of minority issues by Pakistani electronic media in the perspective of ethnocentric behavior, rather media neutrally present the minority issues or not. It is measured that media covered minority issues but with an ethnic side. Forty three percent (43\%) of the people agreed that leading news channels support nationalism while reporting minority issues. Forty five percent (45\%) public replied that media created hype regarding minority issue to some extent. Fifty percent (50\%) approved that news media promote conflict between Muslims and non-Muslims. The hypotheses of the research approved that media objectively covered the incident. The researcher analyzed that public's opinion is directly associated with the media agenda that leading news channels set in the presentation of issues but to some extent audience regrets media's target purpose. The researcher concluded that media must follow the media ethics that are not only beneficial for them but also for the development of society.

\section{Limitations:-}

There are some limitations of the study which should be mentioned before analyzing and interpreting data.

1. The researcher has purposively selected Kot Radha Kishan issue for the convenience of research and to manage time.

2. The study is limited to the minority issues.

3. The present study does not intend to measure media content, only know about coverage of the issue from the public.

4. The researcher only focuses on the public of Lahore.

\section{References:-}

1. Abu Bakar, H., \& McCann, R. M. (2016). The Mediating Effect of Leader-Member Dyadic Communication Style Agreement on the Relationship Between Servant Leadership and Group-Level Organizational Citizenship Behavior. Management Communication Quarterly, 30(1), 32-58. http://doi.org/10.1177/0893318915601162

2. Bakar, H. A., Mohamad, B., \& Mustafa, C. S. (2007). Superior-Subordinate Communication Dimensions and Working Relationship: Gender Preferences in a Malaysian Organization. Journal of Intercultural Communication Research, 36(1), 51-69. http://doi.org/10.1080/17475750701265282

3. Bohensky, E. L., \& Leitch, A. M. (2014). Framing the flood: A media analysis of themes of resilience in the 2011 Brisbane flood. Regional Environmental Change, 14(2), 475-488. http://doi.org/10.1007/s10113-0130438-2

4. Chan, K., Tsang, L., \& Ma, Y. (2015). Consumers' attitudes toward advertising by traditional Chinese medicine practitioners. Journal of Asian Pacific Communication, 25(2), 305-322. http://doi.org/10.1075/japc.25.2.11cha

5. Greenberg, B. S., \& Mastro, D. E. (2009). Children, Race, Ethnicity, and Media. In The Handbook of Children, Media, and Development (pp. 74-97). http://doi.org/10.1002/9781444302752.ch4

6. Groshek, J., \& Han, Y. (2011). Negotiated Hegemony and Reconstructed Boundaries in Alternative Media Coverage of Globalization. International Journal of Communication, 5, 1523-1544.

7. Ho, S. S., Chen, V. H.-H., \& Sim, C. C. (2013). The spiral of silence: examining how cultural predispositions, news attention, and opinion congruency relate to opinion expression. Asian Journal of Communication, 23(2), 113-134. http://doi.org/10.1080/01292986.2012.725178

8. Hsu, S. Y., \& Barker, G. G. (2013). Individualism and collectivism in Chinese and American television advertising. International Communication Gazette, 75(8), 695-714. Retrieved from http://www.scopus.com/inward/record.url?eid=2-s2.0-84887570172\&partnerID=tZOtx3y1

9. McCombs, M. E., \& Shaw, D. L. (1972). The Agenda-Setting Function of Mass Media. The Public Opinion Quarterly, 36(2), 176-187. http://doi.org/10.1086/267990

10. Newman, N., Dutton, W. H., \& Blank, G. (2012). Social Media in the Changing Ecology of News : The Fourth and Fifth Estates in Britain. International Journal of Internet Science, 7(1), 6-22. http://doi.org/10.2139/ssrn.1826647

11. Okazaki, S., Mueller, B., \& Taylor, C. R. (2010). Global Consumer Culture Positioning: Testing Perceptions of Soft-Sell and Hard-Sell Advertising Appeals Between U.S. and Japanese Consumers. Journal of International Marketing, 18(2), 20-34.

12. Pandyan, K. (2013). The coming of age of Indian animation. Journal of Asian Pacific Communication, 23231(10), 66-85. http://doi.org/10.1075/japc.23.1.05pan

13. Raza, S. H., \& Awan, S. M. (2013). Discourse Analysis of Coverage Regarding Drone Attacks: A study of Pakistani Print Media. Pakistan Journal of Social Sciences, 33(2), 379-388.

14. Raza, S. H., Bakar, H. A., \& Mohamad, B. (2017). Relationships between the Advertising Appeal and Behavioral Intention: The Mediating role of the Attitude towards Advertising Appeal. In SHS Web of 
Conferences 33, 00022 (2017) (pp. 1-6). http://doi.org/10.1051/ SHS Web of Conferences 33, 00022 (2017) shsconf $/ 20173300022$

15. Raza, S. H., \& Hussain, S. S. (2016). News Coverage of Physical Violence against Women: Where Do We Position. Journal of Culture, Society and Development, 19, 75-81.

16. Raza, S. H., Kaharal, W. K., \& Bhatti, M. A. (2017). ATTACK ON MALALA: FRAMING OF THE INCIDENT IN THE PRINT MEDIA. VFAST Transactions on Education and Social Sciences, 12(1), 1-7.DOI: http://dx.doi.org/10.21015/vtess.v12i1.428

17. Raza, S. H., \& Khan, M. A. (2014). Study of Gender Sensitive Reporting on Crime News in Dawn \& Khabarain. Pakistan Journal of Social Sciences, 34(2), 625-636.

18. Raza, S. H., \& Liaqat, M. (2016). HONOR KILLING OF WOMEN : A COMPARATIVE STUDY OF THE PAKISTANI PRINT MEDIA. VFAST Transactions on Education and Social Sciences, 10(1).DOI: http://dx.doi.org/10.21015/vtess.v10i1.419

19. Raza, S., \& S.Waheed. (2016). New Media and Mass Communication Relationship of the Celebrity Endorsement in the T.V Advertisements and Buying Behavior of Youth. ISSN, 52, 2224-3267. Retrieved from www.iiste.org

20. Scheufele, D. A., \& Tewksbury, D. (2007). Framing, agenda setting, and priming: The evolution of three media effects models. Journal of Communication.

21. Shan, Y., \& King, K. W. (2015). The Effects of Interpersonal Tie Strength and Subjective Norms on Consumers' Brand-Related eWOM Referral Intentions. Journal of Interactive Advertising, (April), 1-12. http://doi.org/10.1080/15252019.2015.1016636

22. Siegel, A. (2016). "Oh no, it's just culture." Journal of Asian Pacific Communication, 26(2), 193-215. http://doi.org/10.1075/japc.26.2.02sie

23. Sparks, C. (2007). Globalization, development and the mass media. Globalization, Development and the Mass Media. http://doi.org/10.4135/9781446218792

24. Sung, C. C. M. (2014). Hong Kong university students' perceptions of their identities in English as a Lingua Franca contexts: An exploratory study. Journal of Asian Pacific Communication, 24(1), 94-112. http://doi.org/10.1075/japc.24.1.06sun

25. Wang, W.-T., \& Li, H.-M. (2012). Factors influencing mobile services adoption: a brand-equity perspective. Internet Research, 22(2), 142-179.

26. Zhang, Y. B. (2006). The Portrayal of Older Adults in Advertising: A Cross-National Review. Journal of Language and Social Psychology, 25(3), 264-282. 